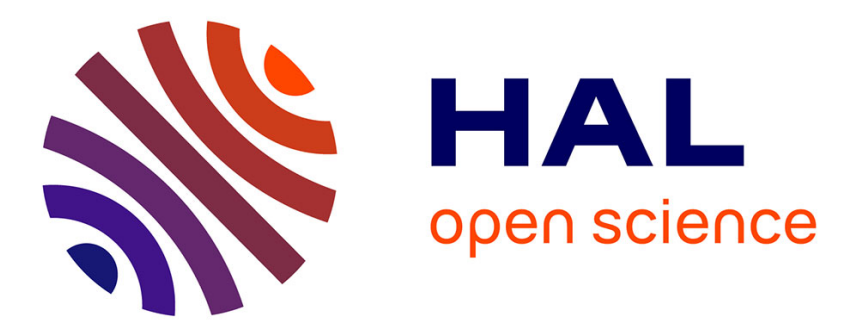

\title{
The 'ephemeral' intensive care units that saved the French healthcare system, a new concept to be preserved
}

Franck Verdonk, Marc Garnier, Francis Bonnet, Matthieu Jabaudon

\section{To cite this version:}

Franck Verdonk, Marc Garnier, Francis Bonnet, Matthieu Jabaudon. The 'ephemeral' intensive care units that saved the French healthcare system, a new concept to be preserved. European Journal of Anaesthesiology, 2021, 38 (4), pp.441-442. 10.1097/EJA.0000000000001320 . hal-03162686

\section{HAL Id: hal-03162686 \\ https://hal.sorbonne-universite.fr/hal-03162686}

Submitted on 8 Mar 2021

HAL is a multi-disciplinary open access archive for the deposit and dissemination of scientific research documents, whether they are published or not. The documents may come from teaching and research institutions in France or abroad, or from public or private research centers.
L'archive ouverte pluridisciplinaire HAL, est destinée au dépôt et à la diffusion de documents scientifiques de niveau recherche, publiés ou non, émanant des établissements d'enseignement et de recherche français ou étrangers, des laboratoires publics ou privés. 
The "ephemeral" intensive care units that saved the French healthcare system, a new concept to be preserved

\author{
F. Verdonk ${ }^{1,2}$, M. Garnier ${ }^{1}$, F. Bonnet ${ }^{1}$, M. Jabaudon ${ }^{3,4}$ \\ ${ }^{1}$ Department of Anesthesiology and Intensive Care, Hôpital Saint-Antoine, Assistance Publique-Hôpitaux de \\ Paris, Paris, France \\ ${ }^{2}$ Department of Anesthesiology, Perioperative and Pain Medicine, Stanford University School of Medicine, \\ Stanford, California \\ ${ }^{3}$ Department of Perioperative Medicine, CHU Clermont-Ferrand, Clermont-Ferrand, France \\ ${ }^{4}$ Division of Allergy, Pulmonary, and Critical Care Medicine Vanderbilt University Medical Center, Nashville
}

The COVID-19 crisis has placed intense pressure on national healthcare systems, particularly in intensive care units (ICU), where existing bed capacity was quickly deemed insufficient. In France, at the peak of the pandemic, 30,375 patients were hospitalized, including 7,148 critically ill patients, far exceeding the usual capacity of 5,432 ICU beds ${ }^{1}$.

The French healthcare system's response to this influx of critical patients revealed its flexibility, already demonstrated five years earlier during the Paris terrorist attacks ${ }^{2}$. This allowed for the optimal management of COVID-19 patients, with an estimated mortality of $0.7 \%$, ranging from $0.001 \%$ to $10.1 \%$, depending on patient age ${ }^{3}$. The flexibility was attributed to two factors: 1 ) the ability to create "ephemeral" ICUs on premises not originally designed for critical hospitalization, as observed in other countries ${ }^{4}$, allowing France to triple ICU bed availability (up to 14,000) in under three weeks; and 2) competent intensive care personnel that could be rapidly mobilized, with the first factor being fully dependent on the second.

In this context, the European specificity of a corpus of physicians who are both anesthesiologists and intensivists is a formidable asset. Firstly, thanks to their initial medical education and mixed practice, 11,000 French anesthesiologist-intensivists became almost exclusively intensivists during this period. They have medicalized the ICU beds according to the usual ratio of one specialist for every two patients in France ${ }^{5}$, even though the country usually has only 2,290 specialists working in ICUs. Secondly, through their pivotal role in perioperative patient management, the anesthesiologistintensivists federated non-medical personnel, such as nurse anesthetists and post-anesthesia care nurses, in the management of COVID-19 patients. Consequently, over this period, ICU admission of critically ill COVID-19 patients was not limited by healthcare capacity. Finally, as patient numbers decline, they will be particularly invested in the reorganization of the healthcare system. Until the pandemic is averted, the necessary number of care structures for COVID-19 patients must be maintained while also resuming "normal" activity, particularly surgical activity for patients whose care has been delayed.

It seems that the right response to this-and the next-pandemics lies in the flexibility and adaptability of healthcare structures and medical specialties. We should not aim to keep all ICUs open or increase the number of ICUs, whatever the economic and human cost; instead, we should promote the "ephemeral" ICU. With this strategy, anesthesiologist-intensivists can contribute to the collective interest.

\title{
References
}

1. Nombre de lits de réanimation, de soins intensifs et de soins continus en France, fin 2013 et 2018 Ministère des Solidarités et de la Santé at <https://drees.solidarites-sante.gouv.fr/etudes-et- 
statistiques/publications/article/nombre-de-lits-de-reanimation-de-soins-intensifs-et-de-soinscontinus-en-france>

2. Hirsch M, Carli P, Nizard R, Riou B, Baroudjian B, Baubet T, Chhor V, Chollet-Xemard C, Dantchev N, Fleury N, Fontaine JP, Yordanov Y, Raphael M, Burtz CP, Lafont A: The medical response to multisite terrorist attacks in Paris 2015; 386:pp 2535-8

3. Salje H, Tran Kiem C, Lefrancq N, Courtejoie N, Bosetti P, Paireau J, Andronico A, Hozé N, Richet J, Dubost C-L, Strat Y Le, Lessler J, Levy-Bruhl D, Fontanet A, Opatowski L, Boelle P-Y, Cauchemez S:

Estimating the burden of SARS-CoV-2 in France. Science (80-) 2020:eabc3517

doi:10.1126/science.abc3517

4. Peters AW, Chawla KS, Turnbull ZA: Transforming ORs into ICUs. N Engl J Med 2020

doi:10.1056/nejmc2010853

5. Leone M, Constantin JM, Dahyot-Fizelier C, Duracher-Gout C, Joannes-Boyau O, Langeron O, Legrand M, Mahjoub Y, Mirek S, Mrozek S, Muller L, Orban JC, Quesnel C, Roquilly A, Virat A, Capdevila X: French intensive care unit organisation 2018; 37:pp 625-7

Author Contributions: Conceptualization, F.V.; supervision, F.B. and M.G.; writing-original draft preparation, F.V. and M.J.; writing-review and editing, F.V. and M.J.

\section{Acknowledgments:}

Assistance with the study: none

Financial support and sponsorship: none

Conflicts of interest: none 